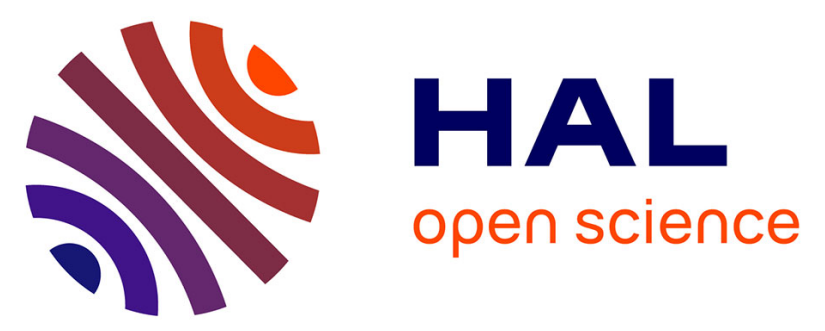

\title{
The lithostratigraphy of the Les Echets basin, France: tentative correlation between cores
}

\author{
Daniel Veres, Barbara Wohlfarth, Valérie Andrieu-Ponel, Svante Björck, \\ Jacques-Louis de Beaulieu, Gunnar Digerfeldt, Philippe Ponel, Linda Ampel, \\ Emmanuel Gandouin, Soumaya Belmecheri
}

\section{To cite this version:}

Daniel Veres, Barbara Wohlfarth, Valérie Andrieu-Ponel, Svante Björck, Jacques-Louis de Beaulieu, et al.. The lithostratigraphy of the Les Echets basin, France: tentative correlation between cores. Boreas, 2007, 36 (3), pp.326-340. 10.1080/03009480601061020 . hal-02959144

\section{HAL Id: hal-02959144 \\ https://hal-amu.archives-ouvertes.fr/hal-02959144}

Submitted on 6 Oct 2020

HAL is a multi-disciplinary open access archive for the deposit and dissemination of scientific research documents, whether they are published or not. The documents may come from teaching and research institutions in France or abroad, or from public or private research centers.
L'archive ouverte pluridisciplinaire HAL, est destinée au dépôt et à la diffusion de documents scientifiques de niveau recherche, publiés ou non, émanant des établissements d'enseignement et de recherche français ou étrangers, des laboratoires publics ou privés.

\section{(ㄷ)(1) $\$$}

Distributed under a Creative Commons Attribution - NonCommerciall 4.0 International 


\title{
The lithostratigraphy of the Les Echets basin, France: tentative correlation between cores
}

DANIEL VERES, BARBARA WOHLFARTH, VALÉRIE ANDRIEU-PONEL, SVANTE BJÖRCK, JACQUES-LOUIS DE BEAULIEU, GUNNAR DIGERFELDT, PHILIPPE PONEL, LINDA AMPEL, SIWAN DAVIES, EMMANUEL GANDOUIN AND SOUMAYA BELMECHERI

\begin{abstract}
Veres, D., Wohlfarth, B., Andrieu-Ponel, V., Björck, S., de Beaulieu, J.-L., Digerfeldt, G., Ponel, P., Ampel, L., Davies, S., Gandouin, E. \& Belmecheri, S. 2007: The lithostratigraphy of the Les Echets basin, France: tentative correlation between cores. Boreas, Vol. 36, pp. 000-000. Oslo. ISSN 0300-9483.

Two new long sediment cores (EC1 and EC3), recovered from different locations within the infilled basin at Les Echets, France, provide a new high-resolution record of terrestrial and lacustrine responses to climatic changes during Marine Isotope Stages (MIS) 3 and 2. The lithologies of the cores are described in detail and correlated with each other by stratigraphic marker horizons, fluctuations in organic matter and AMS radiocarbon ages. The tentative correlation of the new cores to those described and analysed by de Beaulieu et al. (1980) and de Beaulieu \& Reille (1984a) provides a preliminary chronostratigraphic framework. Sedimentation during MIS3 started with accumulation of sands and silts and was followed by alternating gyttja and clayey gyttja silts. Exceptionally high sedimentation rates during MIS2 led to the infilling of the basin. Alternating organic-rich and minerogenicrich sediments appear to coincide with changes in pollen assemblages (de Beaulieu \& Reille 1984a) and suggest that millennial-scale climatic changes controlled lake productivity and catchment stability during most of MIS3.

Daniel Veres (e-mail: daniel.veres@natgeo.su.se), Stockholm University, Department of Physical Geography and Quaternary Geology, SE-10691 Stockholm, Sweden, and 'Emil Racovita' Speleological Institute, Clinicilor 5, 400006 Cluj, Romania; Barbara Wohlfarth and Linda Ampel, Stockholm University, Department of Physical Geography and Quaternary Geology, SE-10691 Stockholm, Sweden; Valérie Andrieu-Ponel, Jacques-Louis de Beaulieu, Philippe Ponel and Emmanuel Gandouin, Université d'Aix-Marseille, Faculté des Sciences de Saint Jérôme, IMEP, UMR CNRS 6116, France; Svante Björck and Gunnar Digerfeldt, Lund University, Department of Geology, GeoBiosphere Science Centre, SE-22362 Lund, Sweden; Siwan Davies, Department of Geography, University of Wales Swansea, Swansea SA2 8P, UK, Soumaya Belmecheri, LSCE (CEA-CNRS), Bât. 709, Orme des Merisiers, F-91191 Gif sur Yvette, France; received 27th March 2006, accepted 26th September 2006.
\end{abstract}

More than 20 years ago, de Beaulieu \& Reille (1984a) presented in Boreas the first results of pollen stratigraphic investigations of a 56-m long lake sediment core obtained from the French site of Les Echets (Fig. 1A). This proved to be an important paper for defining the late Quaternary terrestrial stratigraphy of Europe (de Beaulieu \& Reille 1984b, 1989; Guiot et al. 1989; Pons et al. 1992; van Andel \& Tzedakis 1996; Lowe \& Walker 1997; Cheddadi et al. 1998; Allen \& Huntley 2000; Guiter et al. 2003; Klotz et al. 2004) and confirmed the successive vegetation communities identified by Woillard (1978) within the La Grande Pile sequence.

Sediments started to accumulate in the lake basin of Les Echets during the penultimate termination, corresponding with the uppermost part of Marine Isotope Stage (MIS) 6. The series of successive forest episodes alternating with open vegetation were assigned to the climatic substages of MIS5 (de Beaulieu \& Reille 1984a, 1989). For the middle and upper part of the last glacial period, the pollen stratigraphic record indicated a dominance of cold-tolerant species but also a cyclic occurrence of intervals with high Pinus pollen percentages. Similar features have also been recognized in other long French sequences (Reille \& de Beaulieu
1990; de Beaulieu et al. 2001) and in the laminated lake record from Lago Grande di Monticchio in Italy (Allen et al. 1999).

In addition, results from Lago Grande di Monticchio suggested that the palaeoenvironmental development during the last glacial period was closely linked with climatic changes in the North Atlantic region, where ice cores (e.g. Dansgaard et al. 1993; North Greenland Ice Core Project Members 2004) and marine sediments (e.g. Bond et al. 1993; Rasmussen et al. 1997) indicate a period of severe climatic fluctuations, both in timing and amplitude. Abrupt shifts between stadial conditions and conditions similar to today's climate characterized this time, while extensive ice sheets covered North America and Europe (Svendsen et al. 2004). These rapid shifts between cold and warm conditions have been termed Dansgaard-Oeschger (D-O) stadials and interstadials, respectively. Most of the $\mathrm{D}-\mathrm{O}$ interstadials started with an abrupt increase in temperature, thought to occur within a few decades, and some seem to coincide with ice-free conditions along the coast of Norway (Raunholm et al. 2004) and in northern Finland (Helmens et al. 2000; Sarala et al. 2005; Mäkinen 2005). Evidence for $\mathrm{D}-\mathrm{O}$ events has been inferred from 


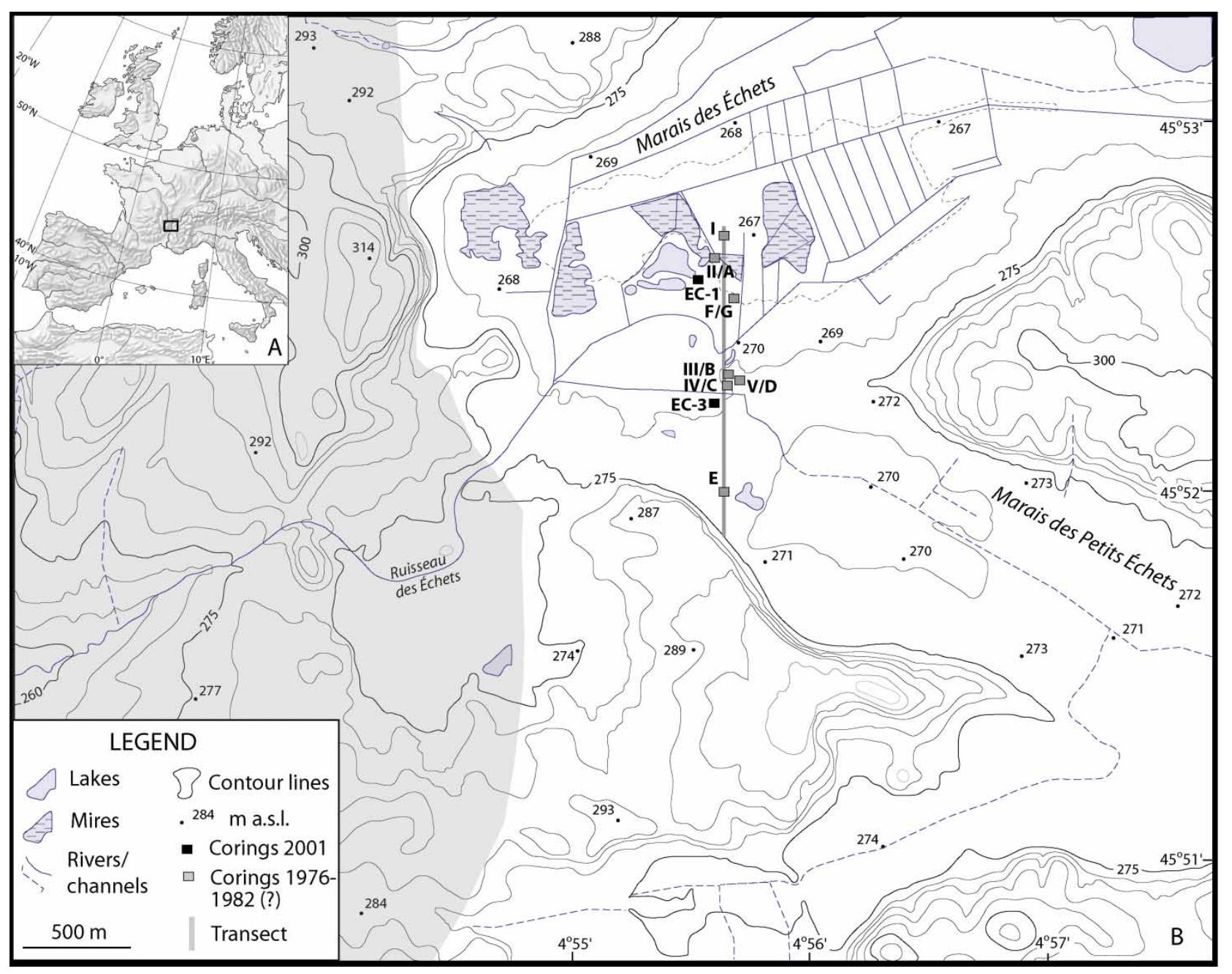

Fig. 1. A. Location of the study area in Europe. B. Topographic map of the Les Echets basin. The new cores EC1 and EC 3 are shown by black squares and previous coring locations by grey squares (de Beaulieu et al. 1980; de Beaulieu \& Reille 1984a). The extent of the mire is approximately equivalent to the $275 \mathrm{~m}$ a.s.l. contour line. The shaded area to the west of the mire marks the Rissian external moraine belt.

a number of different depositional environments in Europe, including marine sediments (Rasmussen et al. 1997; Shackleton et al. 2000; Sánchez-Goñi et al. 2002), speleothems (Spötl \& Mangini 2002; Genty et al. 2003) and lake sediments (Allen et al. 1999; Tzedakis et al. 2004) (see also review by Voelker et al. 2002), suggesting a strong atmospheric teleconnection between marine and continental areas during the last glacial cycle.

In light of these findings from the North Atlantic region, a multiproxy study of the long lake sediment sequence at Les Echets seemed timely for a number of reasons. First, the site offers the potential for highresolution studies of MIS3 and MIS2 (de Beaulieu \& Reille 1984a; Voelker et al. 2002). Second, the landscape is open to the northwest, making it possible that the site records $\mathrm{D}-\mathrm{O}$ events driven by changes in marine and atmospheric conditions in the North
Atlantic region and that the signals would not be biased by orographic effects. Third, earlier investigations focused solely on pollen stratigraphy and a multiproxy investigation and detailed chronology were lacking, which prevented correlations with other records during parts of MIS4 and MIS3 (de Beaulieu \& Reille 1984a; Allen \& Huntley 2000). Finally, the timing and spatial extent of the Alpine ice sheet and glacial dynamics in the region during MIS4 to MIS2 are not well constrained chronologically (Monjuvent \& Winistorfer 1980; Mandier 1984; Florineth \& Schlüchter 2000). Given the location of the site in between the Alpine moraine belts (de Beaulieu et al. 1980; Mandier 1981), crucial information can potentially be extracted from the record of Les Echets by employing a multiproxy approach together with a detailed chronological framework. This record could also form an important link between the well-defined 
Fig. 2. Simplified geological map of Les Echets area (adapted after J. Brulhet, pers. comm. 2006).

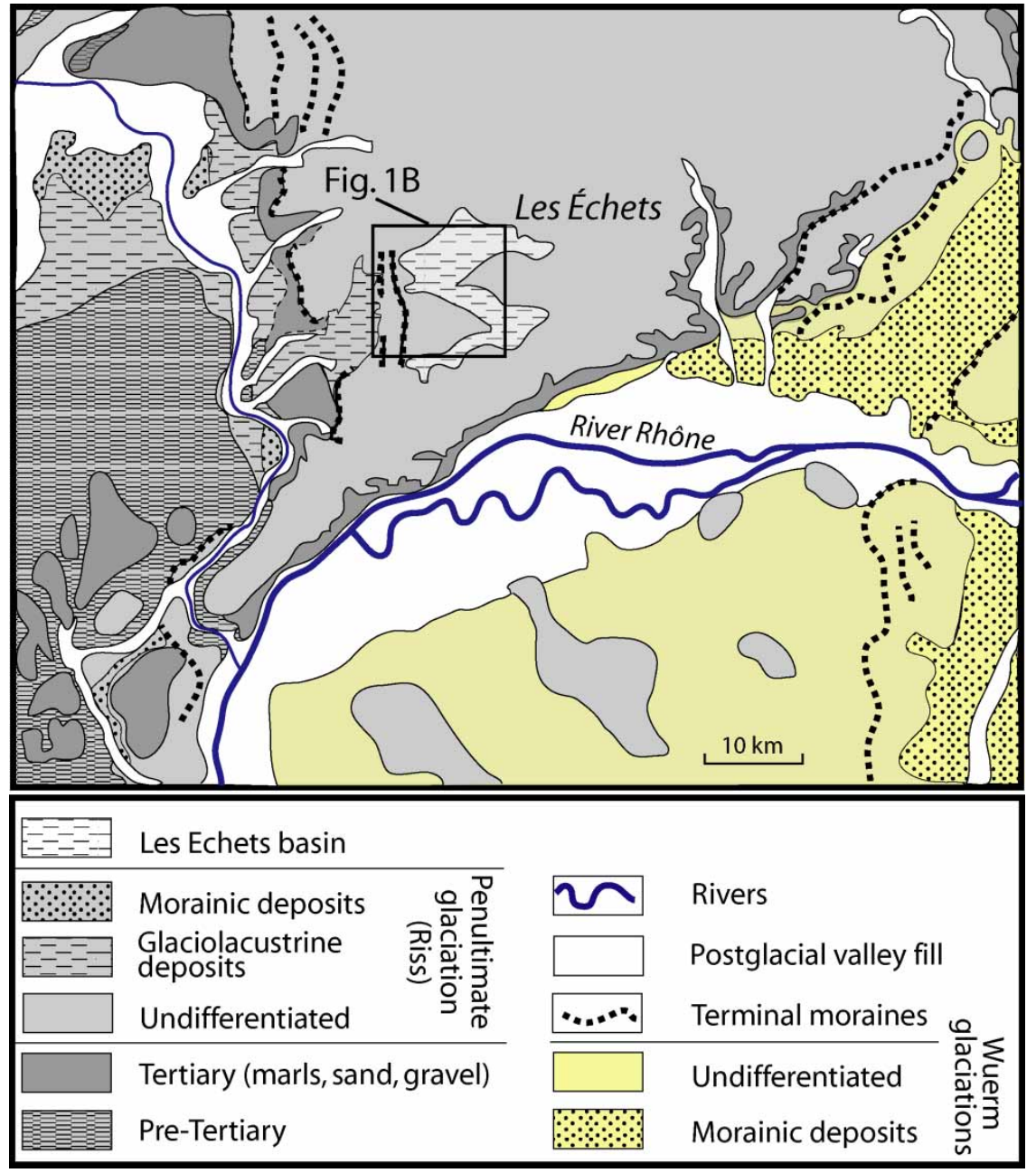

southern European pollen records (Allen et al. 1999; Tzedakis et al. 2004) and north European pollen stratigraphies, which are still fragmentary (de Beaulieu et al. 2001) and thus difficult to correlate precisely (Whittington \& Hall 2002).

New sediment cores were obtained at Les Echets during a coring expedition in the autumn of 2001 (Fig. 1B), with the central aim of investigating whether and how the limnic and terrestrial ecosystem responded to the rapid climate variability during the last $140 \mathrm{kyr}$. This paper is the first in a series directed at a multiproxy re-investigation of the Les Echets sequence for MIS3 and MIS2. The project aimed to constrain the ages of the different temperate periods, earlier recognized in Les Echets during MIS3 and MIS2 (de Beaulieu \& Reille 1984a, b), and provide a detailed reconstruction of the response of the terrestrial ecosystem to the abrupt changes observed in North Atlantic records. Here we present detailed lithostratigraphies of the two new sediment cores, including organic matter content and AMS ${ }^{14} \mathrm{C}$ measurements for the upper $30.06 \mathrm{~m}$ in core $\mathrm{EC} 1$ and $14.55 \mathrm{~m}$ in core
EC3, which cover MIS3 and MIS2. We tentatively correlate these sequences with the previously recovered cores based on distinct lithological markers and radiocarbon ages. This correlation and re-investigation of the lithostratigraphy provides insight into the former depositional environment of this lake basin.

\section{Site description}

Les Echets is a mire $\left(45^{\circ} 54^{\prime} \mathrm{N}, 4^{\circ} 56^{\prime} \mathrm{E}\right)$ located near the town of Lyon on the south-western part of the hilly Dombes Plateau, France (Fig. 1A, B). It is situated c. $4 \mathrm{~km}$ east of the westernmost moraine ridge of the Rissian external moraine complex at an altitude of $267 \mathrm{~m}$ a.s.l. (de Beaulieu et al. 1980) (Fig. 2). The mire itself extends over $13 \mathrm{~km}^{2}$ inside a large glacial basin that covers an area of about $40 \mathrm{~km}^{2}$, and the basin rim reaches a maximum of just over $300 \mathrm{~m}$ on the moraine ridges. The glacial basin is thought to have been excavated during the penultimate glaciation by the Rhône Glacier and dammed by the Rissian frontal 
moraines deposited a few kilometres to the west of the site (de Beaulieu et al. 1980). The hills around the basin are composed of Rissian glaciofluvial and Würmian aeolian deposits, while the basin itself is filled up with c. $60 \mathrm{~m}$ of post-Rissian sediments (Fig. 2). Upper Pliocene and pre-Rissian glaciofluvial deposits are restricted to the southern and western edges of the plateau, while limestones and intrusive rocks outcrop to the west in the Saône valley. Geomorphological evidence indicates that alpine glaciers did not override the site during the Last Glacial Maximum but formed their terminal moraines (internal moraine belt in the Alpine area) approximately $15 \mathrm{~km}$ to the east. Extensive glaciofluvial deposits outcrop in the plains in front of the Würmian terminal moraines. The former lake gradually filled-in at the end of the Würmian and a large peat bog developed (120-130 ha) that today covers $c$. $10 \%$ of the former lake surface. Historical records mention that systematic drainage of the mire began as early as AD 1481 (de Beaulieu \& Reille 1984a) and has continued up to the present day. The area receives average annual precipitations of $830 \mathrm{~mm}$ and mean annual temperatures are around $9.5^{\circ} \mathrm{C}$ (Guiot et al. 1989).

\section{Earlier investigations at Les Echets}

Investigations at Les Echets started several decades ago with a geological survey summarized by de Beaulieu et al. (1980) and Mandier (1981). During the 1970s a series of drilling attempts resulted in the recovery of several cores (cores A-F; Fig. 1B) and the publication of the first composite pollen diagram by de Beaulieu et al. (1980). Mechanized coring in 1979 in the middle of the palaeolake reached the Rissian till at a depth of $56 \mathrm{~m}$ (core G). Above a basal unit of glaciolacustrine, organic-poor laminated clays, the sediment became an intercalation of thick organic-rich gyttjas and marls overlain by a thick succession of clays and silts in the upper $30 \mathrm{~m}$.

The pollen record (upper $39 \mathrm{~m}$ of sediment), starting with the Late Rissian pollen zone A, shows that important changes occurred in the structure of the vegetation, with alternating long-standing periods of closed woodlands, open woodland and tundra (de Beaulieu \& Reille 1984a, b, 1989). Three important periods of forest development are correlated with the Eemian (pollen zone B), Saint Germain 1 (pollen zone D) and Saint Germain 2 (pollen zone F) and mark the middle part of the sequence overlying the late Rissian sediments. The palynostratigraphic record for this part of the sequence allows a secure comparison with other long lacustrine European records (Woillard \& Mook 1982; Follieri et al. 1988; Reille \& de Beaulieu 1990; Reille et al. 2000; de Beaulieu et al. 2001; Allen \& Huntley 2000). Comparisons of palaeotemperature and precipitation estimates between Les Echets and
La Grande Pile produced a highly similar trend for the two sequences (Guiot et al. 1989).

The pollen stratigraphic record above Saint Germain 2 (pollen zones $\mathrm{G}-\mathrm{P}$ ), however, is rather complex and its correlation with other sites is not as straightforward as the lower part of the sequence. The thick silty sediments yielded a pollen assemblage dominated by herbaceous taxa with sporadic peaks in Pinus pollen. de Beaulieu \& Reille (1984a) cautiously interpreted this pollen assemblage as representing sudden and repeated changes in pollen production and delivery from a sparse vegetation cover under cold-temperate and dry climates. Levels with high Pinus percentages and modest rises in Picea and mesophilous tree pollen may point to a minor expansion of nearby regional forest stands. These assemblages were considered minor interstadials (pollen zones $\mathrm{H}, \mathrm{J}$ and $\mathrm{L}$ ) by de Beaulieu \& Reille (1984a). Allen \& Huntley (2000) noted that these pollen zones might correlate with pollen zones 11, 9 or 7 and $5 \mathrm{~b}$ at Lago Grande di Monticchio, which would place them approximately between 50 and $26 \mathrm{kyr}$ BP, but this correlation remained tentative given the lack of a good chronology for Les Echets.

\section{Methods}

A new coring expedition, undertaken in November 2001 by a joint Swedish-French-American team, recovered two new long sediment cores from Les Echets, EC1 and EC3 (Fig. 1B). Core EC1 (44 m long) was drilled in the presumed middle of the palaeolake, approximately $1.15 \mathrm{~km}$ from the palaeoshore, with the intention of replicating core $G$ of de Beaulieu \& Reille (1984a), which had been cored c. $0.3 \mathrm{~km}$ to the southeast. Core EC3 (24.2 m long) was located c. $0.7 \mathrm{~km}$ south of $\mathrm{EC1}$, closer to the former margin of the palaeolake (Fig. 1B). The cores were retrieved with a semi-automatic three-walled stationary piston corer (GEOBOR S $1500 \mathrm{~mm}$ ) equipped with an outer wall that continuously cuts the sediment during the coring operation and allows the recovery of undisturbed sediment sections in $1.5 \mathrm{-m}$ long plastic PVC tubes with a diameter of $11 \mathrm{~cm}$ (G. Seret, pers. comm. 2006). A minor disadvantage of this device is that sediments may become compacted during coring and thus may expand when the cores are opened for investigation. The length of each subcore was measured immediately after drilling and after opening, and sediment decompression was estimated to have been minimal. With the exception of two large sediment gaps in the top and middle parts of core EC3 because of the loss of loose sands, sediment recovery was $98 \%$ of the drilled length. The cores were split in half in January 2002 and their lithostratigraphy was described in detail. Colour changes were assessed using the Munsell colour chart. One subset of cores was stored 
in the archive at IMEP, Aix-en-Provence (France), while the other half was transported to Stockholm University (Sweden) for further subsampling. Because of the large volume of work involved in studying such long sequences at high resolution, the work was divided between two teams within the 'Les Echets working group'. The top part of the sequences, corresponding to $30.06 \mathrm{~m}$ in core $\mathrm{EC} 1$ and $14.55 \mathrm{~m}$ in core $\mathrm{EC} 3$, which cover MIS3 and MIS2, were the object of the present study.

Volumetric samples for weight loss-on-ignition (LOI) analyses were taken in contiguous $2-\mathrm{cm}$ increments, dried at $105^{\circ} \mathrm{C}$ for $12 \mathrm{~h}$ and subsequently ignited at $550^{\circ} \mathrm{C}$ for $4 \mathrm{~h}$ following the method of Heiri et al. (2001). The weight loss during ignition at $550^{\circ} \mathrm{C}$ is regarded as the sediment organic matter content and is expressed as percentage loss (\%) of the original weight. Samples for AMS ${ }^{14} \mathrm{C}$ measurements consisted of unidentified limnic and terrestrial plant material and Phragmites sp. These were dried at $105^{\circ} \mathrm{C}$ overnight in pre-cleaned glass vials before submitting them to the Poznan Radiocarbon Laboratory, Poland. Sample pretreatment included an acid-alkali-acid treatment. Radiocarbon ages are expressed as years before present (BP). The limnic plant remains could be affected by a hard water effect; however, the extent of this has to be evaluated by dating many more samples.

\section{Lithostratigraphy of cores EC1 and EC3}

\section{Core EC1 $(0-30.06 \mathrm{~m})$}

The lowermost unit $\mathrm{H}(30.06-27.48 \mathrm{~m})$ is composed of dark-grey clayey gyttja silts and laminated clayey silt gyttjas, irregularly interbedded with centimetre-thick silts and sands (Fig. 3). The contact between the sandy horizons and the dominant sediment is very sharp and at times erosional. The organic matter content varies between $2 \%$ in the sandy horizons to more than $8 \%$ in the clayey silt gyttjas. Vivianite occurs mostly in the lower part of the unit.

A sharp contact between a silt layer and an olivegrey, silty algae gyttja marks the transition to unit $\mathrm{G}$ $(27.48-22.49 \mathrm{~m})$, which is composed of alternating layers of highly compacted algae gyttjas, rich in organic matter and dark grey clayey gyttja silts with low organic matter content (Fig. 3). The sediments are occasionally laminated and very thin pale olive to pale yellow silt layers are present throughout. Vivianite occurs in the silty algae gyttjas and plant macrofossils (Phragmites sp.) are locally present in sediments with low organic content. The contact between the different layers is gradual. In the lower part of unit $\mathrm{G}$, the organic matter content increases abruptly (over c. $20 \mathrm{~cm}$ of sediment) to $>20 \%$, fluctuates around these values for another $50 \mathrm{~cm}$ and sharply declines to low values again. These cycles are repeated several times, with each cycle covering more than $1 \mathrm{~m}$ of sediment. The last peak in organic matter content (c. $12 \%$ ) in unit $\mathrm{G}$ coincides with blackish grey clayey gyttja silts and is centred around $22.70 \mathrm{~m}$.

A sharp boundary separates unit $\mathrm{G}$ from the overlying unit F (22.49-18.55 m). This unit is composed of alternating clayey gyttja silts and faintly laminated clayey silt gyttjas and shows the same cyclic sedimentation pattern as the preceding unit (Fig. 3). However, the organic content is considerably lower, attaining around $6 \%$ in the clayey gyttja silts and around $12 \%$ in the clayey silt gyttjas. Millimetre-thick layers of clayey silt are occasionally observed. Distinct thin organicrich layers occur in the top part of the unit, while vivianite and $\mathrm{FeS}$ stains occur throughout.

The sharp decline in organic matter content at $18.55 \mathrm{~m}$ coincides with a distinct change in sedimentation at the onset of unit E $(18.55-16.20 \mathrm{~m})$. This unit is composed of a massive, faintly laminated dark grey clayey silt gyttja, which becomes slightly calcareous in the upper part. The organic content fluctuates around $8 \%$. Distinct thin layers of beige clayey silt occur and coarse plant macrofossils are present. AMS radiocarbon dating of Phragmites macrofossils at $18.295-18.29 \mathrm{~m}$ depth gave an age of $23890 \pm 150$ ${ }^{14} \mathrm{C}$ BP (Poz-2493).

With the onset of unit D $(16.20-11.55 \mathrm{~m})$, the sediment becomes more minerogenic (Fig. 3). Dark grey partly oxidized and faintly laminated calcareous clayey gyttja silts make up the bulk of this unit. Vivianite occurs frequently. The organic matter content fluctuates around $6 \%$, with values below $4 \%$ at the lower boundary of the unit. Thin horizons of clayey silt gyttjas are present around $14 \mathrm{~m}$ and at the transition to the overlying clayey gyttja silts of unit C. Although the lithology of the sediments in unit $\mathrm{C}$ $(11.55-5.91 \mathrm{~m})$ is similar to unit $\mathrm{D}$, the sediments appear to be more massive and are only discretely laminated and partly oxidized. This monotonous sedimentation is interrupted at $5.91 \mathrm{~m}$ by the appearance of sandy sediments rich in coarse organics that mark the onset of the overlying unit B (5.91-0.68 m). This unit is composed of grey clayey gyttja silts with frequent calcareous sandy layers, thin organic layers, sands and faintly laminated silty clays. This alternation of sediments produces an oscillating pattern in the organic matter content, varying between $2 \%$ and $10 \%$. Root structures and FeS stains are visible in the upper part. Plant remains from an organic-rich layer between $5.69 \mathrm{~m}$ and $5.63 \mathrm{~m}$ depth gave an age of $17090 \pm 90$ ${ }^{14} \mathrm{C}$ BP (Poz-2492).

The sequence is capped by a $0.5-\mathrm{m}$ thick black peat that is overlain by a peaty soil rich in clay lenses. The whole of this organic-rich horizon (peat and peaty soil) is distinguished as unit $\mathrm{A}(0.68-0 \mathrm{~m})$. The upper peaty soil is probably disturbed by agriculture. 
Core EC3 $(0.3-15.80 \mathrm{~m})$

Unit $\mathrm{H}$ comprises the sediment between $14.55 \mathrm{~m}$ and $13.00 \mathrm{~m}$ and has sharp lower and upper boundaries (Fig. 4). It starts with a $10-\mathrm{cm}$ thick silty gyttja layer overlain by a clayey silt horizon that inversely grades upwards into massive sandy gyttja silts with occasional fine sand layers (Fig. 4). The contact at $14.55 \mathrm{~m}$ is probably erosional, and the majority of the underlying sand layer was lost during coring because of its loose nature.

Unit $\mathrm{H}$ is sharply overlain by an alternation of organic-rich gyttja horizons and thick gyttja silts that make up unit $\mathrm{G}(13.00-6.45 \mathrm{~m})$. This unit can be separated into three subunits (Fig. 4): $13.00-11.00 \mathrm{~m}$, $11.00-9.40 \mathrm{~m}$ and $9.40-6.45 \mathrm{~m}$. The lower subunit between $13.00 \mathrm{~m}$ and $11.00 \mathrm{~m}$ consists of two silt gyttja layers separated by faintly laminated gyttja silts. The organic matter content rises abruptly to values around $25 \%$ in the silt gyttjas and oscillates around 5\% in the gyttja silts. Between $11.00 \mathrm{~m}$ and $9.40 \mathrm{~m}$, the sediment is made up of laminated sandy clayey gyttja silts alternating with thin layers of gyttja silts. FeS staining is frequent and coarse organic matter occurs throughout but is not abundant. The organic matter content is low but rises gradually towards the top of the subunit. Three minor peaks reaching around $9 \%$ occur in the middle of the subunit. A sudden change in lithology at $9.40 \mathrm{~m}$ marks the transition to $3 \mathrm{~m}$ of alternating darkgrey silt gyttjas and light-coloured gyttja silts. The organic matter trend follows these lithological changes, with five well-developed peaks of $10 \%$ or higher, alternating with low values of around 5\%. Although the change in lithology is gradual, the rise to high organic matter values and the return to low values occur abruptly.

Unit F (6.45-4.90 m) starts with the appearance of massive FeS-stained slightly calcareous clayey gyttja silts, with a coarsening upwards trend (Fig. 4). Some coarse organic material occurs in the lower part of the unit and becomes abundant upwards. A few thin silt layers are observed in the top part. The organic matter content oscillates between $2 \%$ and $6 \%$. A radiocarbon age of $23640 \pm 150{ }^{14} \mathrm{C} \mathrm{BP}$ (Poz-2494) was obtained on bulk sediment between $4.98 \mathrm{~m}$ and $4.88 \mathrm{~m}$ depth.

The overlying succession of faintly laminated clayey silts and clayey silt gyttjas, alternating with silty gyttja clays, that starts at $4.90 \mathrm{~m}$ is defined as unit E (4.90$3.60 \mathrm{~m}$ ). The sediment is rich in calcareous clasts, coarse organic matter and vivianite. The contact between individual horizons is sharp and the organic matter content varies between $2 \%$ and $5 \%$.
A sudden drop in the organic matter content between $3.60 \mathrm{~m}$ and $3.25 \mathrm{~m}$ depth to values below $2 \%$ marks a change in sediment type to grey sandy clayey silt (Fig. 4). Coarse organic material and carbonate clasts occur occasionally. This horizon is capped by a package of massive silty sands with low organic content $(<2 \%)$ but rich in carbonate clasts. The sediment between $2.10 \mathrm{~m}$ and $1.65 \mathrm{~m}$ was lost during coring. Above this gap, the sediment becomes coarser, massive and rich in plant macrofossils. The organic matter content fluctuates between $0 \%$ and $5 \%$. The top $85 \mathrm{~cm}$ are made up of pebbly and gravelly silty gyttjas with fluctuating organic matter content $(0-10 \%)$. This part of the sequence is probably disturbed by late agricultural activities. The whole of the sediment between $3.60 \mathrm{~m}$ and $0.3 \mathrm{~m}$ is grouped as unit $\mathrm{D}-\mathrm{B}$.

\section{Correlation between cores EC1 and EC3}

Cores EC1 and EC3 were drilled in different parts of the former lake basin (Fig. 1B): EC1 was drilled close to the presumed centre of the basin and EC3 closer to the former shore. The different locations of the two profiles within the basin have certainly created different depositional environments, affecting sediment composition and deposition. We might expect more continuous deposition of fine-grained organic sediments in the deeper part of the basin, while clastic and coarser grained sediments accumulated around the margin of the basin. Also, the deeper site may have been less sensitive to changes in water levels compared with the marginal core, where lake level variations may have resulted in periods of non-deposition or reworking. Figure 5 shows a tentative correlation between cores EC1 and EC3, based on lithological markers, radiocarbon ages and trends in organic matter content but also taking into account the respective location of the cores and the resulting differences in sediment lithology and sedimentation rate.

The two sequences can be well correlated for the lowermost unit, $\mathrm{H}$. This is the only interval in the two cores that shows abundant detrital sandy layers, suggesting that the sediments below $27.48 \mathrm{~m}$ in core EC1 might be contemporaneous with the sediments below $13.00 \mathrm{~m}$ in EC3. The well-sorted sandy layers are intercalated in clayey gyttja silts (EC1) and sandy gyttja silts (EC3) and may indicate oscillations in water level over shorter time intervals and/or periodical delivery of coarser sediments from the lake catchment.

Unit $\mathrm{G}$ is characterized by alternating layers of clayey gyttja silt, algae gyttja and clayey silt gyttja (EC1) and slightly more minerogenic sediments (clayey

Fig. 3. Lithostratigraphy, radiocarbon ages and organic matter content (LOI) of Les Echets core EC1 (1.50-30.00 m) (see Fig. 5 for legend). The undulating horizontal lines mark erosional layer boundaries. The length of the individual subcores is shown by grey bars. Two intervals with contrasting lithologies are detailed in the expanded views to the right of the figure. 
Les Echets Core EC 1

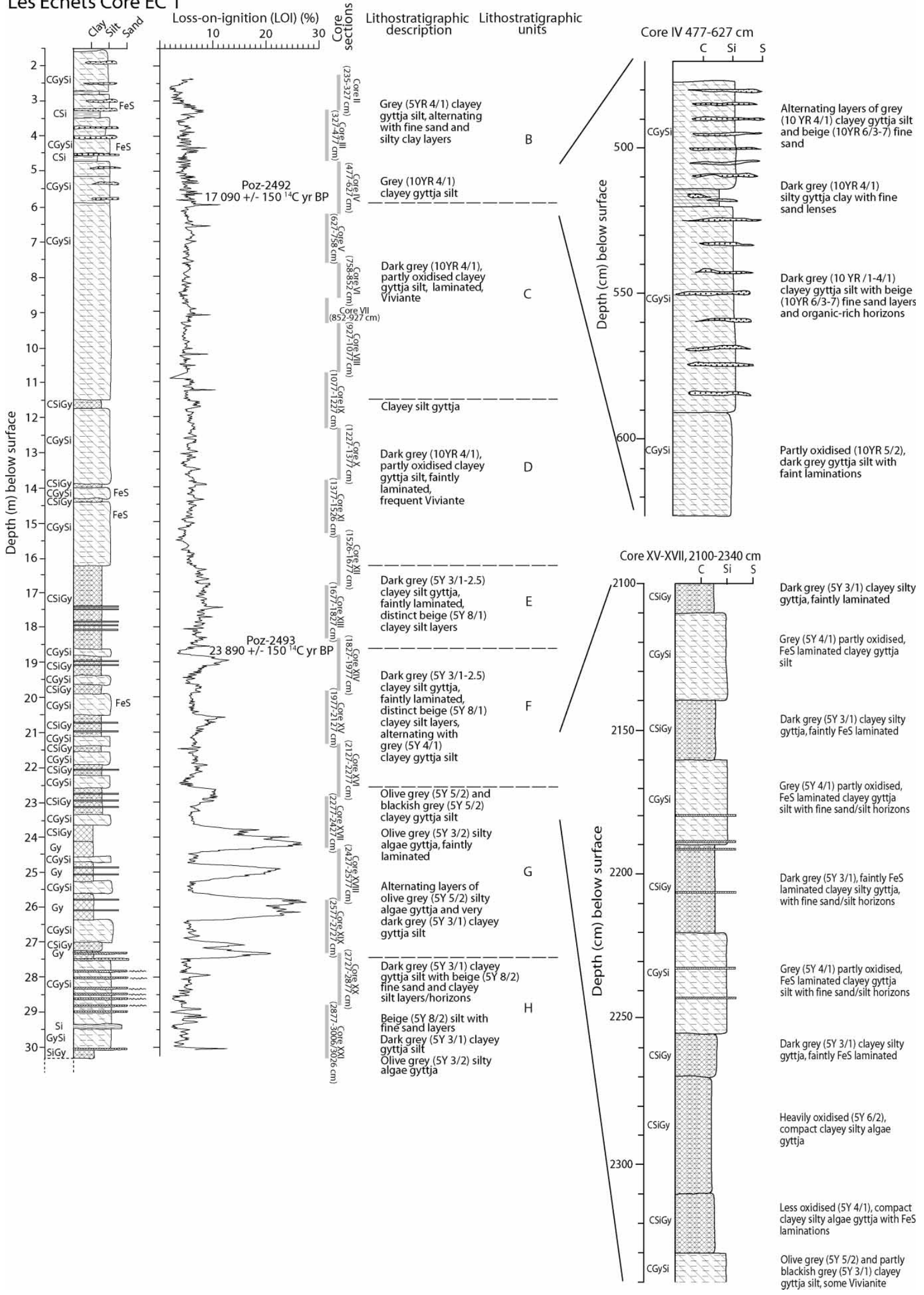

Fig. 3 (Continued) 


\section{Les Echets core EC 3}

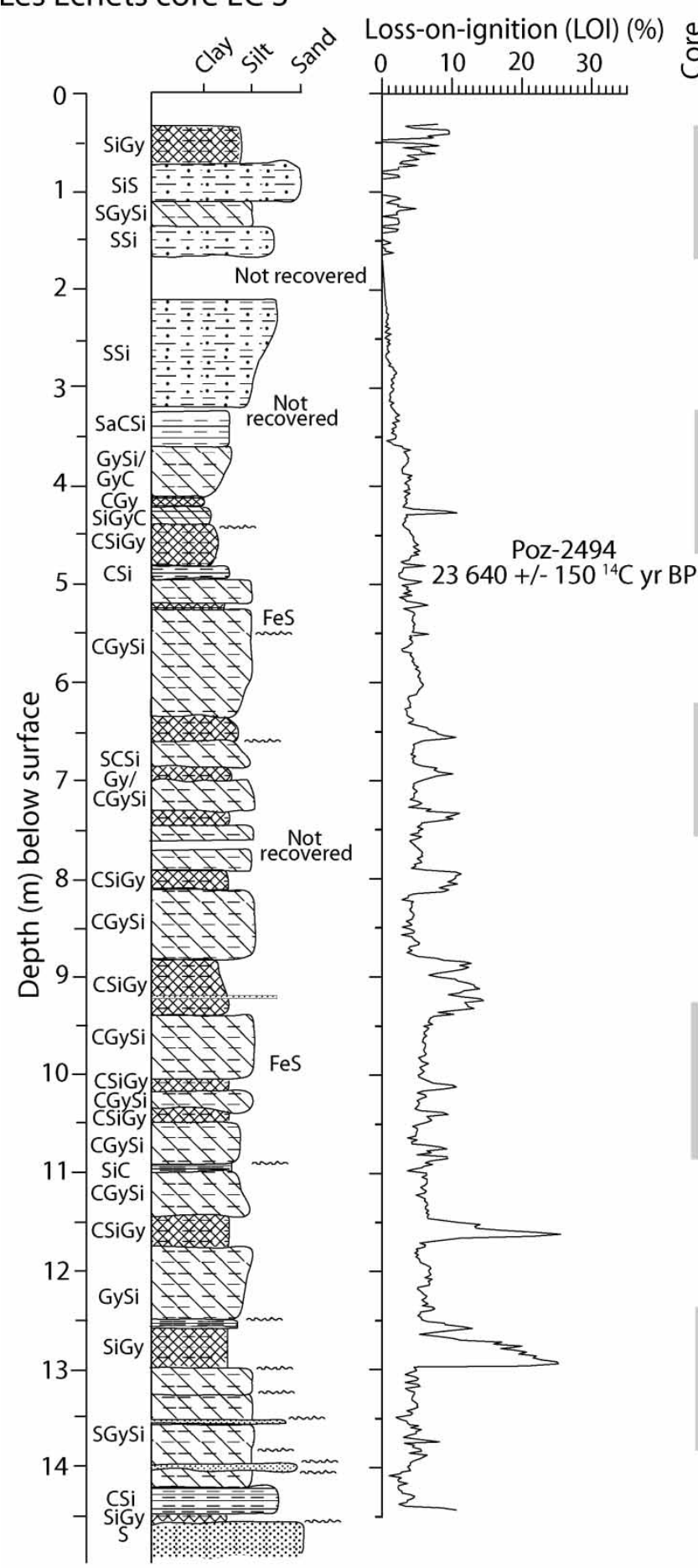

Lithostratigraphic description

Lithostratigraphic units

Dark grey brown (2.5Y 3/2) silty

gyttja, coarse organic matter

Yellow (2.5 7/4) silty fine sand

Rust coloured (5YR 5/6) clayey

sandy gyttja silt

$B-D$

Grey $(2.5 Y 7 / 6)$ to brownish-grey (2.5 $Y 7 / 2)$ sandy silt

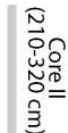

Grey $(2.5 Y 7 / 10)$ sandy silt, carbonate clasts

๘. Grey $(2.5 \mathrm{Y} 6 / 0)$ sandy clayey silt

Do Dark grey (2.5 Y 4/0) clayey gyttja silt/

silty gyttja clay, carbonate clasts

$\S^{\ddagger}$ Dark grey (2.5 Y 4/0) clayey silt gyttja,

alternating with silty gyttja clay

a Dark grey (2.5Y 4/0) clayey silt

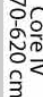

Dark grey (5Y 4/1) calcareous

clayey gyttja silt

E

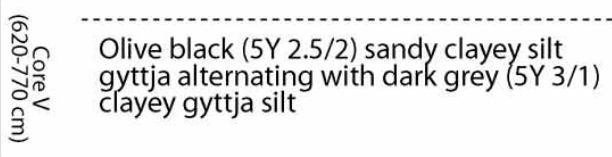

Olive grey (5Y 4/2) sandy clayey gyttja silt

I Dark grey (5Y 3/1) clayey silt gyttja

응 Dark grey (5Y 3/1) clayey gyttja silt

$\bigcap_{3}$ Black grey $(5 Y 3 / 1)$ to olive grey $(5 Y 3 / 2)$, compact sandy silty clay gyttja, faintly laminated

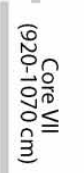

Dark grey (5Y 4/1) laminated

G sandy clayey gyttja silt alternating with silt gyttja

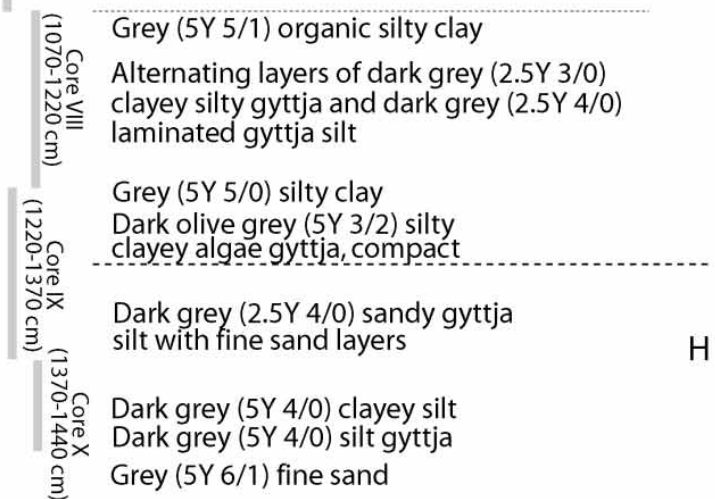

Fig. 4. Lithostratigraphy, radiocarbon ages and organic matter content (LOI) of Les Echets core EC3 (0.30-14.55 m) (see Fig. 5 for legend). The undulating horizontal lines mark erosional layer boundaries. The length of the individual subcores is shown by grey bars.

gyttja silt and clayey silt gyttja) in EC3 (Fig. 5). The alternation between more minerogenic and more organic sediments is clearly reflected in the organic matter content, which in this unit displays the most distinct variations in both sequences. We therefore assume that sediments between $27.48 \mathrm{~m}$ and $22.49 \mathrm{~m}$ in $\mathrm{EC} 1$ and between $13.00 \mathrm{~m}$ and $6.45 \mathrm{~m}$ in EC 3 belong to the same sedimentary facies. Increased catchment 


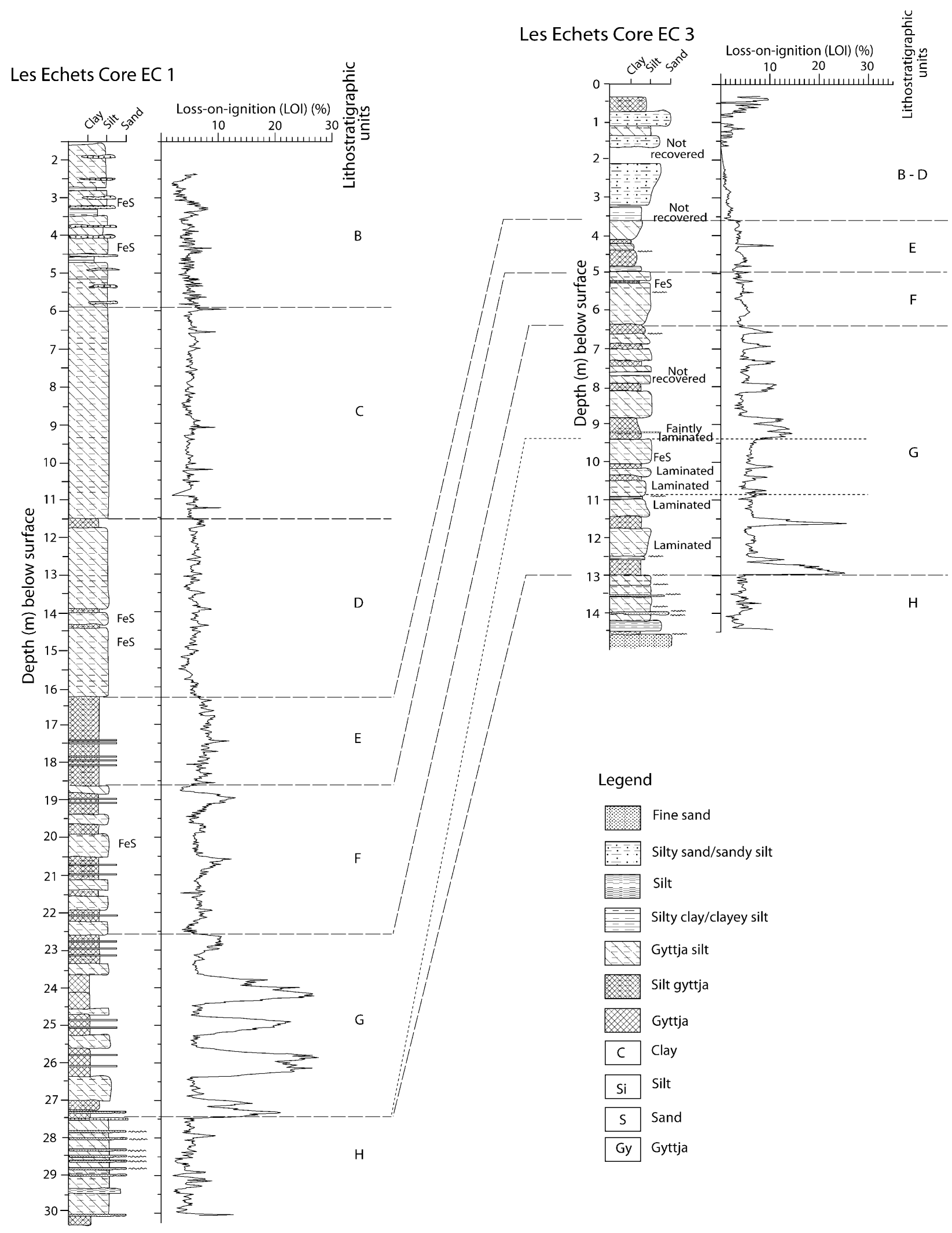

Fig. 5. Lithostratigraphic correlation (dashed lines) between Les Echets cores EC1 and EC3 based on lithological markers and the organic matter content (LOI). The dotted line indicates where the correlation is uncertain. The undulating horizontal lines mark erosional layer boundaries. 
erosion as a result of decreased vegetation cover during colder periods might have delivered more minerogenic sediments to the lake basin, while the algae gyttjas reflect higher aquatic productivity during more temperate intervals. Moreover, Phragmites macrofossils in layers with low organic matter content could indicate lower lake levels, while the algae gyttjas were probably deposited during periods with higher water levels. Sediments between $13.00 \mathrm{~m}$ and $9.50 \mathrm{~m}$ in core EC3 cannot be directly correlated with core EC1. The shape and amplitude of the organic matter peaks between $13.00 \mathrm{~m}$ and $11.00 \mathrm{~m}$, as well as the interval with stable medium to high organic content between $11.00 \mathrm{~m}$ and $9.40 \mathrm{~m}$, are features that are not recognizable in core EC1. Consequently, this would imply that either more sediment accumulated in the marginal part compared with the deeper part of the basin or the sediments in $\mathrm{EC1}$, which are equivalent to the lower part of unit $\mathrm{G}$ in EC3, were eroded after their deposition. If dramatic lake-level changes took place, these could indeed have led to a partial erosion of older layers and could explain why the bottom part of unit $G$ (between $13.00 \mathrm{~m}$ and $9.40 \mathrm{~m}$ ) in core EC3 is missing in core EC1 (Fig. 5). However, as sediments are lacking in the deeper EC1 site, it would require erosion from bottom currents, perhaps as countercurrents to the dominating wind direction and focused on the deeper parts of the basin.

Based on the sediment lithology and organic matter curve, we assume that the clayey gyttja silt between $6.45 \mathrm{~m}$ and $4.90 \mathrm{~m}$ (unit F) in core EC3 could possibly correlate with the clayey silt gyttjas and gyttja silts encountered in core EC1 between $22.49 \mathrm{~m}$ and $18.55 \mathrm{~m}$ (Fig. 5). The sediments in unit $\mathrm{E}$ are made up of clayey silt gyttja, which in EC3 are overlain by gyttja silt/ gyttja clay, indicating slightly more minerogenic deposition in marginal areas. The age of $23890 \pm 150{ }^{14} \mathrm{C}$ $\mathrm{BP}$ at $18.29 \mathrm{~m}$ in EC1 is close to the age of $23640 \pm 150$ ${ }^{14} \mathrm{C}$ BP obtained at $4.88-4.98 \mathrm{~m}$ in $\mathrm{EC} 3$, which supports the correlation. Additionally, the marked decline in organic matter content at the transition to unit $\mathrm{D}$ is a feature recognizable in both cores and may represent a synchronous event.

At $16.20 \mathrm{~m}$ the sediments in EC1 change to massive, faintly laminated clayey gyttja silts with no indications of hiatuses or erosional boundaries between the different layers that make up units D and C (Fig. 5). The low organic matter content may be a consequence of low aquatic productivity under cold climatic conditions and/or dilution of the organic fraction by high input of minerogenic particles (Meyers \& LallierVergès 1999). High sedimentation rates for units $D$ and $\mathrm{C}$ are indeed indicated by the radiocarbon ages of $23890 \pm 150{ }^{14} \mathrm{C}$ BP and $17090 \pm 90{ }^{14} \mathrm{C}$ BP obtained at $18.29 \mathrm{~m}$ and $5.69-5.63 \mathrm{~m}$, respectively. The presence of vivianite coatings on macrofossils may also indicate that the organic matter was buried rapidly, probably under anaerobic conditions (Fagel et al. 2005).
Anaerobic conditions would have prevented bioturbation of the sediment, which in turned would have favoured the preservation of sediment laminations in this part of the sequence.

Unit B $(5.91-0.68 \mathrm{~m})$ in core EC1 is composed of calcareous sediments with sand lenses, which may indicate sediment starvation and a low-energy sedimentary environment in this late stage of basin infilling. As a whole, units D-B may be interpreted as reflecting the gradual infilling of the basin. The package of sediments above unit $\mathrm{E}$ in both cores suggests that high and variable sedimentation rates for the distal units were associated with shoreward thinning and upward coarsening for the littoral areas (Figs 5,6). The coarse minerogenic sediments overlying unit $\mathrm{E}$ in EC3 cannot be further subdivided but probably indicate deposition in shallow water and may be synchronous with units $\mathrm{D}-\mathrm{B}$ in $\mathrm{EC} 1$. The slopes adjacent to the mire are made up of unconsolidated and unsorted glaciofluvial deposits. During times of little vegetation cover (e.g. MIS2) and increased slope instability, these deposits could have provided the sediment for rapid infilling of the basin, which was probably achieved shortly after $17090 \pm 90$ ${ }^{14} \mathrm{C}$ BP (Poz-2492). Moreover, reworking of sediments from the littoral zone, as a result of changes in water level, might have been an important supplier of sediment to the middle of the lake. In addition, the occurrence of nearby aeolian sediments points to the fact that airborne particles may account for a large part of the sediments corresponding to MIS2 (de Beaulieu \& Reille 1984a).

The uppermost unit A in core EC1 has no counterpart in EC3 and indicates that the marginal areas of the lake had already been filled in at the time of deposition of unit $\mathrm{A}$ in $\mathrm{EC} 1$.

\section{Correlation of cores EC1 and EC3 to the earlier investigated sequences}

Based on detailed pollen stratigraphy, de Beaulieu \& Reille (1984a) attempted to correlate the littoral cores IV-C, III-B and V-D of de Beaulieu et al. (1980) and the centre core $G$ (Figs 1B, 6, Table 1). Their correlation showed that a number of hiatuses are evident in both sequences and that only parts of the pollen zones recognized in the central core $\mathrm{G}$ are present in the marginal cores III-V/B-D.

The sequence between $30 \mathrm{~m}$ and $36 \mathrm{~m}$ in core $\mathrm{G}$ is composed of alternating layers of gyttja and clayey silt (pollen zones $\mathrm{B}-\mathrm{F}$ ) and correlates with the interval between $17 \mathrm{~m}$ and $23 \mathrm{~m}$ in marginal cores III-V/B-D (Table 1) (de Beaulieu et al. 1980; de Beaulieu \& Reille 1984a). This succession has a pollen signal typical of vegetation development during the Eemian, Melisey 1, Saint Germain 1, Melisey 2 and Saint Germain 2 


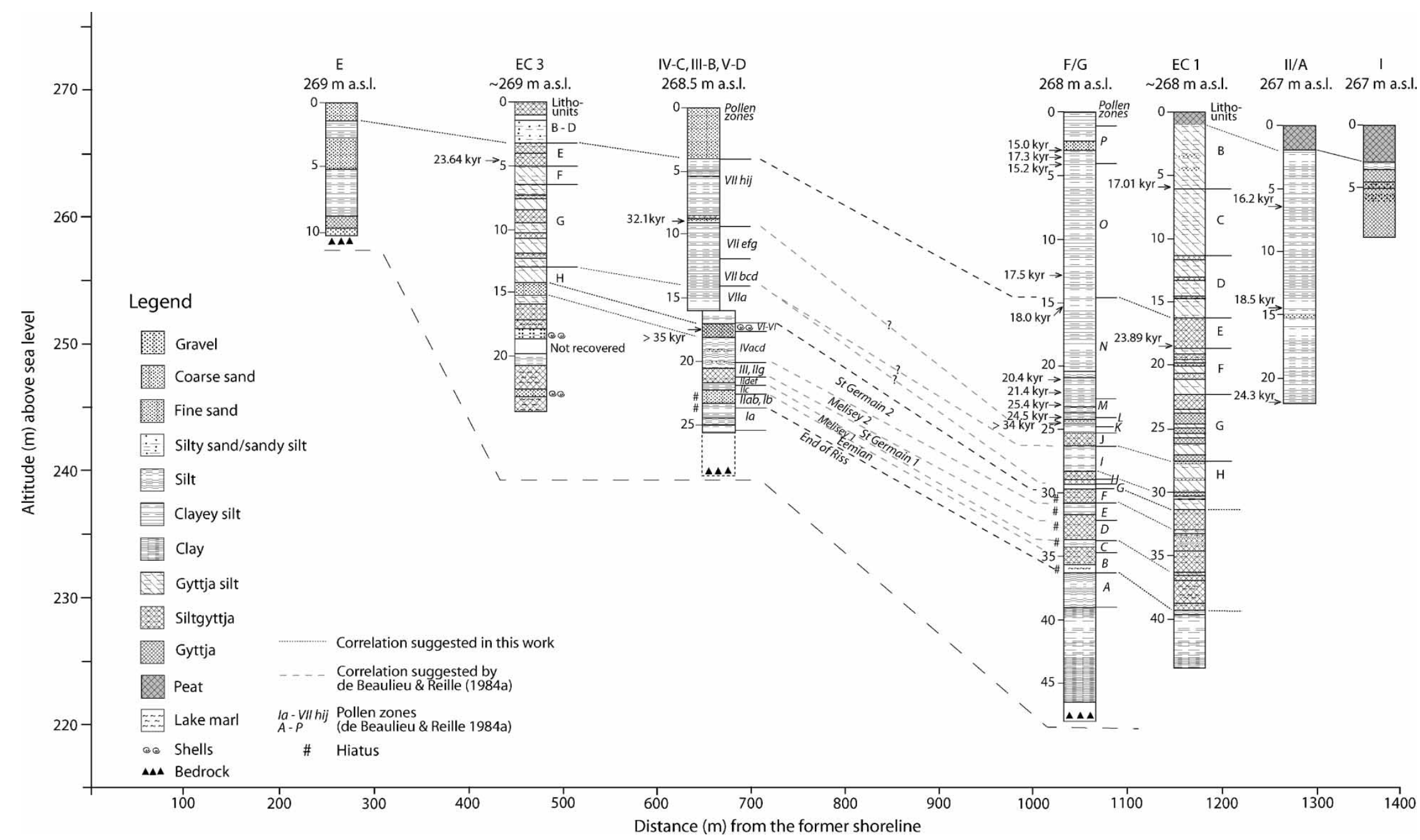

Fig. 6. Stratigraphic transect (south to north) through the Les Echets basin (adapted from Mandier 1981) combining data from previous drillings (see Fig. 1B and Table 1) and the new cores EC1 and EC3. Details on the lithology and palaeoenvironmental interpretation of cores I, II-A, III-B, IV-C, V-D, E and F/G are given in de Beaulieu et al. (1980) and de Beaulieu \& Reille (1984a, b, 1989) and are summarized in Table 1. 
Table 1. Pollen stratigraphic correlation between core $\mathrm{G}$ and the littoral cores (III-V/B-D) and summary of the main climatic events identified by de Beaulieu et al. (1980) and de Beaulieu \& Reille (1984a, b, 1989) at Les Echets.

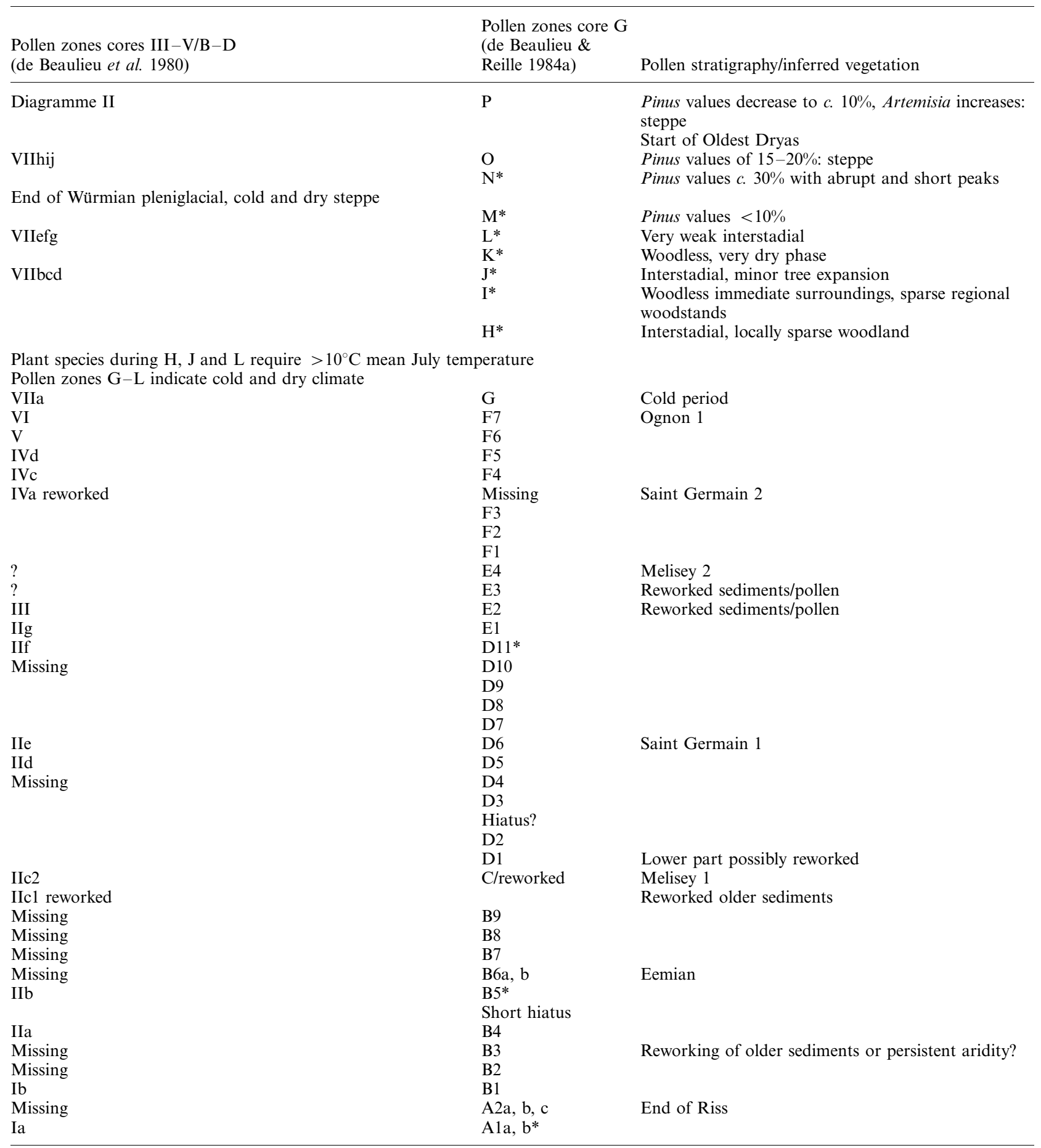

*Correlation uncertain.

in France (de Beaulieu \& Reille 1989; Reille \& de Beaulieu 1990; Reille et al. 2000; Pons et al. 1992) and in the Mediterranean region (Allen \& Huntley 2000; Tzedakis et al. 2004). The sediment succession between $38 \mathrm{~m}$ and $31 \mathrm{~m}$ in core EC1 that overlays the glacial clays/silts can be correlated lithologically to core $\mathrm{G}$ and therefore attributed to the Eemian, Melisey 1, Saint Germain 1, Melisey 2 and Saint Germain 2. 
Similarly, the sequence of layers between $24 \mathrm{~m}$ and $14 \mathrm{~m}$ in EC3 seems to be equivalent to the interval between $23 \mathrm{~m}$ and $18 \mathrm{~m}$ in cores III-V/B-D (Fig. 6).

The pollen stratigraphies for the Middle and Upper Würmian $(<30 \mathrm{~m}$ in core $\mathrm{G}$ and $<14 \mathrm{~m}$ in cores IIIV/B-D) were difficult to correlate (de Beaulieu et al. 1980; de Beaulieu \& Reille 1984a, b). It was tentatively suggested that pollen zones $\mathrm{G}-\mathrm{L}$ in core $\mathrm{G}$ may be equivalent to zones VIIa-VIIefg in the marginal core and that pollen zones $\mathrm{M}-\mathrm{O}$ may correspond to pollen zones VIIhij (Fig. 6, Table 1). Frequent hiatuses in the marginal sequence indicate periods of lake-level changes, which complicate a precise correlation with core G (de Beaulieu \& Reille 1984a). Moreover, rapid infilling of the basin (pollen zones $\mathrm{M}-\mathrm{P}$ ) and/or low lake levels may have led to non-deposition in marginal areas. The sediments corresponding to pollen zones $\mathrm{G}-\mathrm{L}$ in core $\mathrm{G}$ are composed of alternating layers of gyttja, gyttja silts and clayey silt and show an alternation between cold and dry woodless periods (pollen zones $\mathrm{G}, \mathrm{I}$ and $\mathrm{K}$ ) and periods with locally sparse wood stands (pollen zones $\mathrm{H}, \mathrm{J}$ and L), with mainly Pinus but also some Picea (de Beaulieu \& Reille 1984a). The pollen stratigraphic correlation between core $G$ and cores III-V/B-D suggests hiatuses in the sediment record of the marginal cores corresponding to pollen zones H, I and K (Table 1). Although pollen zones $\mathrm{M}-\mathrm{P}$ are mainly characterized by steppe elements, Pinus pollen values reach nearly $30 \%$ in zone $\mathrm{N}$ and show a number of abrupt and short peaks (de Beaulieu $\&$ Reille 1984a) that could indicate either long-distance transport of pollen or the presence of some pine trees in the region. Radiocarbon dates for pollen zones $\mathrm{L}-\mathrm{N}$ obtained between $14.50 \mathrm{~m}$ and $24 \mathrm{~m}$ in core $\mathrm{G}$ give ages of between 18000 and $24500{ }^{14} \mathrm{C} \mathrm{BP}$ and infinite ages at around $24.50 \mathrm{~m}$ (Fig. 6).

Assuming that cold-dry periods in our sequence are represented by more minerogenic sediments and low aquatic productivity, and warmer intervals by higher organic matter and higher aquatic productivity, the changes in lithology in cores EC1 and EC3 may be correlated with the vegetation succession and climatic inferences (cold-dry vs. warm) suggested by de Beaulieu \& Reille (1984a). Based on the lithology and organic matter values, we therefore tentatively correlate the sediment succession between $31.00 \mathrm{~m}$ and $27.48 \mathrm{~m}$ in $\mathrm{EC} 1$ and between $14.00 \mathrm{~m}$ and $13.00 \mathrm{~m}$ in EC3 with the interval comprising pollen zones $\mathrm{G}-\mathrm{I}$ in core $\mathrm{G}$ and pollen zone VIIa in cores III-V/B-D, respectively (Fig. 6). Lithological units $\mathrm{G}-\mathrm{E}$ in core EC1 $(27.48-18.55 \mathrm{~m})$ and EC3 $(13.00-3.60 \mathrm{~m})$, which display marked variations in organic matter content and as such distinct changes in lake productivity, lake levels or erosion, very probably have a counterpart in pollen zones $\mathbf{J}-\mathrm{N}$ in core $\mathrm{G}$ and pollen zones VIIbcdVIIhij in cores III-V/B-D, where minor interstadials alternate with colder intervals. The predominantly clastic sediments with low organic matter in lithological units $\mathrm{D}-\mathrm{B}$ document rapid infilling of the lake basin, possibly under cold and dry climatic conditions. These units may correspond with pollen zones $\mathrm{O}-\mathrm{P}$, for which steppe vegetation and extreme cold-dry climates have been inferred (de Beaulieu \& Reille 1984a). Moreover, radiocarbon dates of between 17500 and $15000{ }^{14} \mathrm{C}$ $\mathrm{BP}$ in pollen zones $\mathrm{O}-\mathrm{P}$ in core $\mathrm{G}$ indicate rapid sedimentation and compare well with the age of 17010 ${ }^{14} \mathrm{C}$ BP obtained for EC1 at $5.69-5.63 \mathrm{~m}$.

The tentative correlation of cores EC1 and EC3 with the pollen stratigraphic record of cores $\mathrm{G}$ and III-V/ $\mathrm{B}-\mathrm{D}$ shows that the sediments above $31 \mathrm{~m}$ in EC1 and above $14 \mathrm{~m}$ in EC3 were deposited during the middle and upper part of the last glacial, i.e. correspond with MIS3-2. However, only the combination of pollen stratigraphy with other environmental proxy data and an independent chronology will allow a precise characterization of the different warm-cold intervals that occurred during this time and their correlation with other archives. Still, our preliminary data show that the new sequence obtained at Les Echets will form an important contribution for a better understanding of the rapid climatic shifts that prevailed during the last glacial period and their impact on the terrestrial environment.

\section{Conclusions}

Two long sediment cores (EC1 and EC3) recently recovered from the Les Echets basin have been investigated and correlated based on detailed lithostratigraphy and fluctuations in organic matter content. A chronostratigraphic framework for the two sequences is based on AMS radiocarbon dates and an intrabasin correlation is proposed for the two new sediment cores and the lithostratigraphic data summarized by de Beaulieu et al. (1980) and de Beaulieu \& Reille (1984a). Based on these correlations, we conclude that the two new cores span MIS3 and MIS2, with three distinct periods of lake development evident during this time interval. Coarse sands and silts poor in organic matter accumulated at the onset of MIS3, while cyclic deposition of relatively organic-rich and organic-poor sediments characterize a large part of MIS3. Massive and rapid sedimentation of highly minerogenic sediments occurred during most of MIS2. The lake ultimately filled in during MIS2 and an extensive Holocene peat bog developed. We also note that there are substantial sedimentological differences between the proximal and distal areas of the former lake. The littoral areas support a more discontinuous, clastic sedimentation while the centre of the lake is more complete, rich in finer sediment and organic matter. Based on the intrabasin transect, we show that the sediment supply to the lake increased significantly during MIS3 and in the later stages of in-filling, providing an exceptional high-resolution 
terrestrial climatic record over MIS3 and MIS2. However, the most intriguing feature of the sequence is the cyclic alternation of relatively organic-rich and organic-poor sediments corresponding with the lithostratigraphic units G and E (MIS3). The organic-rich intervals are easily identifiable and the transitions to and from the minerogenic horizons are sharp but not erosional, indicating that important hydrological and geochemical changes occurred in the lake's regime at the time of their deposition. A close comparison with core G (de Beaulieu \& Reille 1984a) indicates that the cyclic changes in the organic matter content coincide with recurring changes in pollen assemblages, suggesting that millennial-scale climatic changes controlled the lake's productivity and catchment stability during most of MIS3. A high-resolution dating effort as well as a multiproxy analytical investigation is currently in progress that will clarify the nature of these fluctuations and determine their relationship to $\mathrm{D}-\mathrm{O}$ cycles.

Acknowledgements. - We thank J. J. Lowe, an anonymous reviewer and the editor J. A. Piotrowski for their constructive comments and remarks. We are also grateful to T. Lacourse for editing and suggestions on an earlier draft of this paper. This is a contribution to the ESF EuroCores on EuroCLIMATE project RESOLuTION.

\section{References}

Allen, J. R. M. \& Huntley, B. 2000: Weichselian palynological records from southern Europe: correlation and chronology. Quaternary International 73-74, 111-125.

Allen, J. R. M., Brandt, U., Brauer, A., Hubberten, H.-W., Huntley, B., Keller, J., Kraml, M., Mackensen, A., Mingram, J., Negendank, J. F. W., Nowaczyk, N. R., Oberhansli, H., Watts, W. A., Wulf, S. \& Zolitschka, B. 1999: Rapid environmental changes in southern Europe during the last glacial period. Nature 400, 740-743.

van Andel, T. H. \& Tzedakis, P. C. 1996: Palaeolithic landscapes of Europe and environs, $150,000-25,000$ years ago: an overview. Quaternary Science Reviews 15, 481-500.

de Beaulieu, J.-L. \& Reille, M. 1984a: A long Upper Pleistocene pollen record from Les Echets, near Lyon, France. Boreas 13, $111-132$.

de Beaulieu, J.-L. \& Reille, M. 1984b: The pollen sequence of Les Echets (France): a new element for the chronology of the Upper Pleistocene. Géographie Physique et Quaternaire XXXVIII, 3-9.

de Beaulieu, J.-L. \& Reille, M. 1989: The transition from temperate phases to stadials in the long Upper Pleistocene sequence from Les Echets (France). Palaeogeography, Palaeoclimatology, Palaeoeco$\log y$ 72, 147-159.

de Beaulieu, J.-L., Andrieu-Ponel, V., Reille, M., Grüger, E., Tzedakis, C. \& Svobodova, H. 2001: An attempt at correlation between the Velay pollen sequence and the Middle Pleistocene stratigraphy from central Europe. Quaternary Science Reviews 20, $1593-1602$.

de Beaulieu, J.-L., Evin, J., Mandier, P., Monjuvent, G. \& Reille, M. 1980: Les Échets: un marais capital pour l'histoire climatique du Quaternaire Rhodanien. Mémoires du Muséum National d'Histoire Naturelle XXVII, 123-136.

Bond, G., Broecker, W., Johnsen, S., McManus, J., Labeyrie, L., Jouzel, J. \& Bonani, G. 1993: Correlations between climate records from North Atlantic sediments and Greenland ice. Nature 365, $143-147$.
Cheddadi, R., Mamakowa, K., Guiot, J., de Beaulieu, J.-L., Reille, M., Andrieu, V., Granoszewski, W. \& Peyron, O. 1998: Was the climate of the Eemian stable? A quantitative climate reconstruction from seven European pollen records. Palaeogeography, Palaeoclimatology, Palaeoecology 143, 73-85.

Dansgaard, W., Johnsen, S. J., Clausen, H. B., Dahl-Jensen, D., Gundestrup, N. S., Hammer, C. U., Hvidberg, C. S., Steffensen, J. P., Sveinbjörnsdottir, A. E., Jouzel, J. \& Bond, G. 1993: Evidence for general instability of past climate from a 250 -kyr ice-core record. Nature 364, 218-220.

Fagel, N., Alleman, L. Y., Granina, L., Hatert, F., Thamo-Bozso, E., Cloots, R. \& André, L. 2005: Vivianite formation and distribution in Lake Baikal sediments. Global and Planetary Change 46, $315-336$.

Florineth, D. \& Schlüchter, C. 2000: Alpine evidence for atmospheric circulation patterns in Europe during the Last Glacial Maximum. Quaternary Research 54, 295-308.

Follieri, M., Magri, D. \& Sadori, L. 1988: A 250 000-years pollen record from Valle di Castiglione (Roma). Pollen et Spores 30, $329-356$

Genty, D., Blamart, D., Ouahdi, R., Gilmour, M., Baker, A., Jouzel, J. \& Van-Exter, S. 2003: Precise dating of Dansgaard-Oeschger climate oscillations in western Europe from stalagmite data. Nature 421, 833-837.

Guiot, J., Pons, A., de Beaulieu, J.-L. \& Reille, M. 1989: A 140,000year continental climate reconstruction from two European pollen records. Nature 338, 309-313.

Guiter, F., Andrieu-Ponel, V., de Beaulieu, J.-L., Cheddadi, R., Calvez, M., Ponel, P., Reille, M., Keller, T. \& Goeury, C. 2003: The last climatic cycles in western Europe: a comparison between long continuous lacustrine sequences from France and other terrestrial records. Quaternary International 111, 59-74.

Heiri, O., Lotter, A. F. \& Lemcke, G. 2001: Loss on ignition as a method for estimating organic and carbonate content in sediments: reproducibility and comparability of results. Journal of Paleolimnology 25, 101-110.

Helmens, K. F., Räsänen, M. E., Johansson, P. W., Jungner, H. \& Korjonen, K. 2000: The Last Interglacial-Glacial cycle in NE Fennoscandia: a nearly continuous record from Sokli (Finnish Lapland). Quaternary Science Reviews 19, 1605-1623.

Klotz, S., Müller, U., Mosbrugger, V., de Beaulieu, J.-L. \& Reille, M. 2004: Eemian to early Würmian climate dynamics: history and pattern of changes in central Europe. Palaeogeography, Palaeoclimatology, Palaeoecology 211, 107-126.

Lowe, J. J. \& Walker, M. J.C. 1997: Reconstructing Quaternary Environments. 446 pp. Pearson Education Limited, Harlow.

Mäkinen, K. 2005: Dating the Weichselian deposits of southwestern Finnish Lapland. In Ojala, A. E. K. (ed.): Quaternary Studies in the Northern and Arctic regions of Finland, Geological Survey of Finland, Special Paper 40, 79-84.

Mandier, P. 1981: Le marais des Echets: premiers enseignements pour l'histoire climato-stratigraphique du Quaternaire Lyonnais. Bullentin du Laboratoire Rhodanien de Geomorphologie 99, 39-61.

Mandier, P. 1984: Le relief de la moyenne vallée du Rhône au Tertiaire et au Quaternaire: essai de synthèse paléogéographique. Ph.D. dissertation, University of Lyon II, 1025 pp.

Meyers, P. A. \& Lallier-Vergès, E. 1999: Lacustrine sedimentary organic matter records of Late Quaternary paleoclimates. Journal of Paleolimnology 21, 345-372.

Monjuvent, G. \& Winistorfer, J. 1980: Glaciers quaternaires dans les Alpes franco-suisses et leur piedmont. Géologie Alpine 56, $251-282$.

North Greenland Ice Core Project Members. 2004: High-resolution record of northern hemisphere climate extending into the last interglacial period. Nature 431, 147-151.

Pons, A., Guiot, J., de Beaulieu, J.-L. \& Reille, M. 1992: Recent contributions to the climatology of the last glacial-interglacial 
cycle based on French pollen sequences. Quaternary Science Reviews 11, 439-448.

Rasmussen, T. L., van Weering, T. C. E. \& Labeyrie, L. 1997: Climatic instability, ice sheets and ocean dynamics at high northern latitudes during the last glacial period (58-10 KA BP). Quaternary Science Reviews 16, 71-80.

Raunholm, S., Larsen, E. \& Sejrup, H. P. 2004: Weichselian interstadial sediments on Jæren (SW Norway): paleoenvironments and implications for ice sheet configuration. Norwegian Journal of Geology 84, 91-106.

Reille, M. \& de Beaulieu J.-L. 1990: Pollen analysis of a long upper Pleistocene continental sequence in a Velay maar (Massif Central, France). Palaeogeography, Palaeoclimatology, Palaeoecology 80, $35-48$.

Reille, M., de Beaulieu, J.-L., Svobodova, H., Andrieu-Ponel, V. \& Goeury, C. 2000: Pollen analytical biostratigraphy of the last five climatic cycles from a long continental sequence from the Velay region (Massif Central, France). Journal of Quaternary Science 15, 665-685.

Sánchez-Goñi, M. F., Cacho, I., Turon, J.-L., Guiot, J., Sierro, F. J., Peypouquet, J.-P., Grimalt, J. O. \& Shackleton, N. J. 2002: Synchroneity between marine and terrestrial responses to millennial scale climatic variability during the last glacial period in the Mediterranean region. Climate Dynamics 19, 95-105.

Sarala, P. O., Johansson, P. W., Jungner, H. \& Eskola, K. O. 2005: The middle Weichselian interstadial: new OSL dates from southwestern Finnish Lapland. In Kolka, V. \& Korsakova, O. (eds.): Proceedings of the International Field Symposium on Quaternary Geology and Landforming Processes, 56-58. The Peribaltic Group, INQUA, Kola Peninsula.
Shackleton, N. J., Hall, M. A. \& Vincent, E. 2000: Phase relationships between millennial-scale events $64,000-24,000$ years ago. Paleoceanography 15, 565-569.

Spötl, C. \& Mangini, A. 2002: Stalagmite from the Austrian Alps reveals Dansgaard-Oeschger events during isotope stage 3: implications for the absolute chronology of Greenland ice cores. Earth and Planetary Science Letters 203, 507-518.

Svendsen, J. I., Alexanderson, H., Astakhov, V. I., Demidov, I., Dowdeswell, J. A., Funder, S., Gataullin, V., Henriksen, M., Hjort, C., Houmark-Nielsen, M., Hubberten, H. W., Ingólfsson, Ó., Jakobsson, M., Kjær, K. H., Larsen, E., Lokrantz, H., Lunkka, J. P., Lyså, A., Mangerud, J., Matiouchkov, A., Murray, A., Möller, P., Niessen, F., Nikolskaya, O., Polyak, L., Saarnisto, M., Siegert, C., Siegert, M. J., Spielhagen, R. F. \& Stein, R. 2004: Late Quaternary ice sheet history of northern Eurasia. Quaternary Science Reviews 23, 1229-1271.

Tzedakis, P. C., Frogley, M. R., Lawson, I. T., Preece, R. C., Cacho, I. \& de Abreu, L. 2004: Ecological thresholds and patterns of millennial-scale climate variability: the response of vegetation in Greece during the last glacial period. Geology 32, 109-112.

Voelker, A. H. L. \& Workshop Participants. 2002: Global distribution of centennial-scale records for Marine Isotope Stage (MIS) 3: a database. Quaternary Science Reviews 21, 1185-1212.

Whittington, G. \& Hall, A. M. 2002: The Tolsta Interstadial, Scotland: correlation with D-O cycles GI-8 to GI-5? Quaternary Science Reviews 21, 901-915.

Woillard, G. M. 1978: Grande Pile peat bog: a continuous pollen record for the last 140,000 years. Quaternary Research 9, 1-21.

Woillard, G. M. \& Mook, W. G. 1982: Carbon-14 dates at Grande Pile: correlation of land and sea chronologies. Science 215, $159-161$. 